\section{SOCIAL WELFARE TRENDS IN WESTERN SOCIETIES: PRIVATISATION AND THE CHALLENGE TO SOCIAL WORK}

Neil Gilbert

University of California at Berkeley ngilbert@berkeley.edu

\section{TENDENCIAS DEL BIENESTAR SOCIAL EN LAS SOCIEDADES OCCIDENTALES: LA PRIVATIZACIÓN Y EL RETO DEL TRABAJO SOCIAL}

Citation/Cómo citar este artículo: Gilbert, N. (2015). "Social Welfare Trends in Western Societies: privatisation and the challenge to Social Work". Arbor, 191 (771): a200. doi: http:// dx.doi.org/10.3989/arbor.2015.771n1002
Copyright: ( 92015 CSIC. This is an open-access article distributed under the terms of the Creative Commons Attribution-Non Commercial (by-nc) Spain 3.0 License.
ABSTRACT: The paper analyses several key features of the changing landscape of modern welfare states, the major the social forces driving this change, and how change is pertinent to the future of social work practice. The social forces driving change include structural factors such as the demographic transition and globalisation of the economy, as well as sociopolitical variables that involve an understanding of the unanticipated effects of social policies and the increased value attributed to the private sector. The central characteristics of change include a shift in policies away from the protection of labor and toward the promotion of work and the increasing use of the private sector for the production and delivery of social services. The privatisation of social welfare and its implications for social work practice are examined in the light of the challenges in negotiating service contracts.

KEYWORDS: privatisation; welfare state; unit-cost analysis; enabling state; contracting; social expenditures.
RESUMEN: Este artículo analiza varios aspectos claves de la evolución del panorama de los estados de bienestar modernos, las principales fuerzas sociales que impulsan este cambio, y cómo el cambio es pertinente para el futuro de la práctica del Trabajo Social. Las fuerzas sociales que impulsan el cambio son factores estructurales tales como la transición demográfica y la globalización de la economía, así como variables socio-políticas que implican una comprensión de los efectos no previstos de las políticas sociales y el aumento del valor atribuido al sector privado. Las características centrales del cambio incluyen una modificación de las políticas, que se desplazan desde la protección del trabajo hacia la promoción del trabajo, y el uso cada vez mayor del sector privado en la producción y prestación de servicios sociales. La privatización de la seguridad social y sus implicaciones para la práctica del trabajo social se examinan a la luz de los retos en la negociación de la contratación de servicios.

PALABRAS CLAVE: privatización; estado de bienestar; análisis de costes unitarios; estado capacitador; contratación; gasto social. 


\section{INTRODUCTION}

Since the mid-1980s, a number of important policy-reforms have shifted responsibilities for social protection among government, citizens, and the private sector, in many if not most of the advanced industrialized nations. I have described this development as a shift from the welfare state to the enabling state (Gilbert, 2004). Others have labeled this trend as a move to -- the Schumpeterian Workfare State (Jessop, 1994), the Hollow State (Milward and Provan, 1993), the Contract State (Eardley, 1997), the Social Investment State, (Giddens, 1998; Cantillon, 2011) the Active State (Holmqvist, 2010) and the Third Way (Giddens, 1998).

These efforts to rebrand the welfare state signify that a palpable change has occurred, which is reflected in numerous welfare reforms. These reforms were initiated to check the mounting costs of social benefits and to adapt social policies to the competitive demands of markets in the global economy of the $21^{\text {st }}$ century. This paper will analyze the changing landscape of modern welfare states examining several of the key the social forces driving the change, how change is manifest in social welfare policy and a few of the issues raised by these modern developments that are most pertinent to the future of social work practice.

Taking a step back in time we can recall that the period from 1960 to roughly 1980 has been referred to as the Golden Era of welfare state expansion. According to OECD estimates social welfare expenditures nearly doubled from an average 12.3 to $23.3 \%$ of the GDP among the21 member nations of Organization for Economic Co-operation and Development (OECD) at that time. That rate of increase, of course, could not continue - doubling every 20 years social spending would soon reach $100 \%$ of the GDP (Gilbert, 2004).

After 1980 the rate of growth as a percent of GDP slowed and leveled off to the extent that it was almost flat between 1980 and 2007. However if we change the metric from spending as a percent of GDP to spending on a per capita basis, a different picture emerges. That is social spending on a per capita basis continued to rise. The increased funding did not from rising tax rates, as these rates leveled off in the 1990s. However, from 1994 to 2007 total real growth of GDP for the OECD countries averaged $2.6 \%$ annually (Gilbert, 2012). Thus, the increased spending was fuelled by sustained economic growth (which declined after 2007).

\section{FORCES OF CHANGE}

One of the reasons for increased spending is that demand for social benefits continued to rise particularly in response to the aging of the population in the OECD countries. Bismark's state-sponsored social security scheme introduced in 1889 was a good deal for the state, since workers paid into the system until they reached the age of retirement at 65, while life expectancy was only 45 years of age. At the end of the $19^{\text {th }}$ century who would have expected that by 2008 men's life expectancy at birth in Germany would have climbed from 45 to 82 years of age. We are now at the take off point of a major demographic transition. In 2010 there were 3 workers contributing to the support of one retired person, by 2050 this .33 ratio will climb to .66 - an average of $1 \frac{1}{2}$ workers supporting one retired person. Spain of course is not an exception, in fact in some ways it is leading the demographic transition into aging societies. The growth of rate of those 65 and over in Spain will rise from $17 \%$ to $25 \%$ between now and 2030 , and is estimated to reached $34 \%$ by 2050 . Looked at another way by 2050, among the OECD countries Spain will have the $4^{\text {th }}$ highest ratio of the aged population to those in the labour force with almost one worker supporting one retired citizen.

This creates a tremendous fiscal pressure on the welfare state-and especially on the younger generation that has to carry the burgeoning costs of an aging population. Just one example of the intense fiscal strain coming our way is phenomenal costs of dementia care for the elderly in the United States. The price of this care is expected to more than double from \$215 billion in 2010 to $\$ 511$ billion in 2040 (Hurd, Martorell, Delavande, Mullen and Langa, 2013).

Aging is not the only force creating pressure for change. The demographic landscape of family life has changed dramatically. The rise in one-person households (now 20\% of all households in Spain) along with the growth in single parent families and female labor force participation necessitate additional forms of public aid, particularly the provision of daycare for young children (OECD, 2011).

But demographic pressures that continue to push the demand for social spending upward are not the only forces responsible for the changing character of the modern welfare state. While social needs are expanding, constraints on additional welfare spending have tightened in response to the pressures of the globalization. The rapid mobility of capital to 
go where production costs are low has heightened competitive markets, which intensifies pressures to scale back labor rights and welfare benefits. In addition to the pressures from what can be characterized as the large-scale structural forces of demography and globalization, there are also socio/political forces for change emanating from a shift in normative views about the consequences of social policies and the proper relationship between the state and the market. Experiences accumulated over the decades of welfare state growth have taught us much about the unanticipated consequences of social benefits, particularly their disincentive effects. The idea that generous welfare benefits might inhibit one's inclination to work was once viewed as heresy by welfare state advocates. In the U.S. they claimed that such views were "blaming the victims" of market failures. Yet when prudently worded not to blame victims, the same idea, that welfare benefits produce "poverty traps" or "enforced dependency" -- has become the received wisdom of the late 1990s. In short it has become apparent that generous social benefits without conditions can create powerful disincentives to work.

Finally, the collapse of the command-economy in the Soviet Union has raised capitalism's stock to record levels of public approval in the marketplace of ideas. This has been accompanied by increasing faith in the efficiency and productivity of the market economy operating through the private sector, the recent recession notwithstanding. Thus, at least four lines of influence representing complex and multiple forces have created pressures for the transformation of the welfare state. And what gives these pressures particular weight is that in different ways they all push in the same direction (Table I).

That is, the change moves away from the guiding principles of the most progressive welfare states which emphasized (1) universal approach to (2) publicly delivered benefits designed to (3) protect labor against the vicissitudes of the market and are firmly held as (4) social rights --- and toward policies framed by a (1) selective approach to (2) private delivery of provisions designed to (4) promote labor force participation and reinforce (4) individual responsibility. The transformation is from a welfare state to an enabling state, which functions under the guiding principle "public support for private responsibility." Within the new framework social welfare policies are increasingly designed to enable people to take individual responsibility for their financial independence and well-being and to enable the private sector to expand its sphere of activity in governing the welfare market (Table II).

In examining the changing landscape of social welfare policy from this perspective my analysis will focus on the dimension of change that is most relevant to the future of professional social work practice, that is the privatization of social welfare. This analysis will trace the several paths along which the movement toward privatization is gaining momentum and some of the implications for social work.

Table I. Structural and social-political forces for welfare reform: four lines of influence

DEMOGRAPHIC TRANSITION
AGING
DIVORCE RATES
EXTRA-MARITAL BIRTHS
FEMALE LABOR-FORCE PARTICIPATION
GLOBALIZATION OF THE ECONOMY
MOBILITY OF CAPITAL TO WHERE PRODUCTION COSTS ARE LOW
MOBILITY OF LABOR TO WHERE BENEFITS ARE HIGH
KNOWLEGE OF UNANTICIPATED EFFECTS
DISINCENTIVES TO WORK
DEPENDENCY TRAPS
CAPITALISM
PISING FAITH IN MARKET ECONOMY
PRIVATIITION

Adapted from Gilbert, N. (2004), table 2.1, p. 44. 
Table II. Shift in Central Tendencies from Welfare to Enabling State

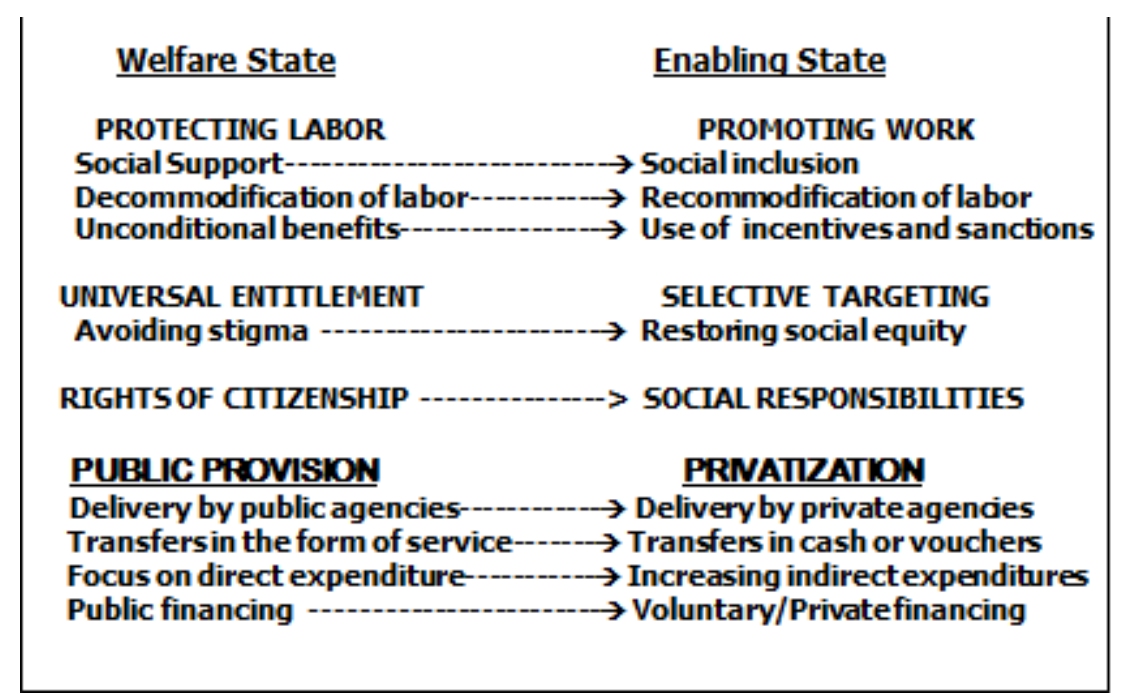

Adapted from Gilbert, N. (2004), table 2.1, p. 44.

\section{PRIVATIZATION}

Historically many welfare states have been built upon a mix of public and private responsibility for both the finance and delivery of social benefits (Gilbert and Terrell, 2005). However, over the last two decades, for the reasons already mentioned, policy makers have come under increasing fiscal pressures to introduce measures that might heighten the efficiency and lower the costs of social protection. In response to these pressures they have sought ways to enlarge the private contribution to the mix of public and private responsibility for social protection. This is done in hopes of reducing public expenditure and increasing quality. In tracing the movement toward privatization one finds at least five major avenues along which the private sector is engaged in the financing, production and delivery of social benefits. Two of these approaches seek to promote greater private financing through providing tax incentives and exercising the regulatory power of government; two other approaches aim to increase private involvement in the production and delivery of social services through the use of vouchers and contractual arrangements for outsourcing services; and one other approach involves a public/private partnership in which private investors put up the initial financing to produce and deliver a social service; they are reimbursed with a profit if the service is shown to be effective in achieving measurable outcomes.

\subsection{Promoting Private Financing}

- Encouragement of private financing thru public tax incentives - public incentives enable private financing through measures such tax credits for day care for the elderly and other tax benefits that partially subsidize private spending on health insurance and pension savings. These are forms of indirect public spending, which are typically calculated under the label of tax expenditures. In the United States one half of the civilian labor force participates in private employment-based pension plans, which receive favorable tax treatment. Although the public sector finances usually more than $90 \%$ of the costs of social benefits, since 1985 there has been a noticeable increase in private spending as a proportion of the gross social expenditures in many OECD countries (Adema and Einerhand, 1998). The US has experienced the largest increase in voluntary private financing, which climbed from just below $6 \%$ of social expenditures in 1985 to $10 \%$ in 2009.

- Publicly-mandated private expenditures for social protection - through legislative mandates the public sector can use the regulatory powers of government to shift some of the costs of social protection to private enterprise. In the Netherlands, for example, the sickness insurance scheme was privatized in 1994, when reforms were introduced that required em- 
ployers to assume the responsibility of paying at least 70 percent of their workers salaries for six weeks of sick leave; in 1996, the period of private coverage was extended to 52 weeks after which workers could qualify for public disability benefits (Geurts, Kompier and Grundemann, 2000). Many governments have introduced legislative reforms, which shift some portion of individual contributions from public pensions to privately managed retirement accounts. Over the last two decades a number of countries have moved toward the privatization of old age pensions by having individuals invest their contributions in private equities. Sweden is a case in point - where $14 \%$ of the workers contributions are invested in private accounts. In Chile the citizens' entire old age pension contribution are privately invested.

\subsection{Private Involvement in the Production and Deli- very of Social Services}

- Substituting benefits in the form of cash or vouchers for public goods and services - allocating public benefits in the form of cash or vouchers stimulates private production and delivery of social provisions. In Sweden, for example, educational vouchers provide parents an opportunity to purchase their children's education from private sources. Currently about $12 \%$ of Swedish students attend schools funded by vouchers. In the United States public housing financed and produced by the state has given way to the provision of housing vouchers that allow low income individuals to rent in the private market.

- Purchasing social protection services from private agencies - purchase-of service arrangements are sometimes referred to as outsourcing. They involve the use of public funds to contract with private agencies - both non-profit and profit making providers - to produce and deliver social services. Since the mid-1990s, there has been an avalanche of multi-million-dollar contracts with for profit organizations to provide welfare case management, training, job-search and placements services, long-term care for the elderly, residential services for children, probation services, health care and many other human services. These third-party-purchase-of-service arrangements can take several forms such as: fixed price, cost plus, and pay for performance (extra profit linked to outcomes) contract.

\subsection{Public/Private Partnerships (PPP)}

The last approach to privatization involves PPP which include: Pay for Success and Social Impact Bonds. These are all slightly different iterations of arrangements under which a private party or group of private investors initially put up the money to fund a human service program. If the privately funded program is successful in achieving agreed upon measurable outcomes, the government reimburses the private parties for their investment including an agreed upon level of profit. These arrangements are relatively new and untested in the realm of social welfare. Britain is credited with pioneering this approach with a prisoner rehabilitation program funded by a Social Impact Bond (SIB) in 2010. In 2012 a program aimed at limiting recidivism among prison inmates was launched in New York City, which included Goldman Sachs among its investors. These arrangements are attracting considerable interest, because they shift the large start-up costs and the financial risk of providing a social program from the public to the private sector (The Economist, February 23, 2013). Private parties assume this risk, which accompanies the start-up of many private enterprises, -- in the hope of producing a successful program for which they will be rewarded with a profit.

\section{PURCHASE OF SERVICES: CHALLENGES AND ISSUES}

Although in recent years privatization has steadily expanded along all of these avenues, the use of public funds to develop contracts with voluntary and forprofit agencies for the delivery of social services has grown in leaps and bounds.

Between 1979 and 1996 the proportion of all public expenditures on personal social services contracted out to the private sector in the United Kingdom more than tripled, from 11-to-34 percent. Most of this increase reflects a change in the provision of residential care which shifted from facilities operated by local authorities to home care under private auspices. Under reforms implemented in 1993, commercial firms are also moving into domiciliary care, services such as inhome meals, cleaning, home nursing, and emergency alarm systems, under contracts with local public authorities who are "expected to be enablers rather than providers" (Johnson, 1995).

Private for-profit arrangements for social welfare are also emerging in Scandinavia. Around the mid1980s Swedish counties that operated local health care systems began contracting for medical services 
with doctors in private practice. Within a decade, Hort and Cohn (1995) report that "what started out as a minor revival of private practice has become a boom." While the public sector provided almost 90 percent of the beds in Swedish residential care facilities for children and youth in the 1970s, by 1995 , close to 60 percent of these beds had shifted over to private institutions (Lundstrom, 2000). In Norway private forprofit providers have increased their share of the residential homes for children and youth. In 1998, they accounted for 33.4 percent of the institutions in this field of service, a 10 percent gain over their share in 1995 (Slettebo, 2000). Social care for the elderly is also moving toward privatization in the Nordic countries. According to Juhani Lehto's (1999) analysis, "This shift from the traditional old age homes to modern service homes means in most Nordic countries a shift from mostly public providers to a more significant role for private non-profit providers". Germany too has experienced an extraordinary increase in for-profit providers in the realm of long term care for the elderly, a field of service from which they were virtually excluded by law up until the mid-1990s. A 2011 study of social services in the European Union by the Employment, Social Affairs and Inclusion Directorate General of the European Commission reports that Germany and the Netherlands rely almost entirely on private sector provision for all long term care services; the study also find that private not-for-profit provision is by far the most prominent way of social housing provision across old EU Member States, and its importance has been growing over the last decade, at the same time in many of the 22 countries studied, the relative importance of for-profit employment services was seen as likely to increase (European Commission, 2011).

The shifting responsibility for the production and delivery of services to the private sector is fueled by the belief that private providers are more responsive and efficient than public bureaucracies. Unlike public bureaucracies, the private sector benefits from the discipline of the market economy wherein competition and consumer signals generate efficiency, accountability and innovation which heightens the quality and lowers the cost of services. All of this boils down to the assumption that where social protection is concerned the private sector can do it cheaper and better.

Indeed, in the United States $3^{\text {rd }}$ party contracts are often less costly than the delivery of social welfare services by public agencies. One reason concerns the price of union labor, particularly the cost of fringe benefits for civil service workers.With the decline in union membership among workers in the private sector over the last several decades, public bureaucracies have emerged as the last stronghold of the labor union movement in the United States. From 1985 to 2010 union membership fell by almost one-third, from 18 percent to 11.9 percent of all wage and salary workers. All of the decline was in the private sector, where union membership slid from 14.4 percent to 6.9 percent of all wage and salary workers -- a drop of about 50 percent. At the same time the percent of union membership represented by the public sector slightly increased. (Hirsch and Macpherson, 2011). The main reason for this holding power is that organized labor in government is largely in the service sector; unlike industrial production, these service jobs could not be shipped overseas to be performed at a lower cost. Instead of being outsourced globally, they are now being outsourced through third-party contracts to the private sector, where social services in the U.S. are not unionized.

However, unlike privatization through the use of vouchers which promote consumer choice, privatization of social services through outsourcing via thirdparty contracts by its very nature fails to generate the kind of consumer signals that serve to regulate cost and quality in the competitive market. Under thirdparty contracts, the first-party-buyer, the government pays for services it does not directly consume, the second-party- the citizen consumes services they do not pay for - while the third-party-the for-profit producer stands in the highly advantageous position of dealing with a buyer who rarely sees what is purchased and a consumer who never bears the expense. This is why Ackerman (1983) proposed the use of proxy-shopping when awarding third-party contracts for service. This scheme would requires that in order to qualify for the award of a service contract the for-profit service provider must be able to show that they already serve a certain percent of paying customers. These customers function as "proxy shoppers" for public funders. That is, government uses the behaviour of private consumers to indirectly monitors the cost and quality of private services. However, this approach is rarely employed. In the absence of consumer signals, purchaseof-service arrangements seek to promote quasi-market conditions by awarding service contracts on the basis of competitive bidding among potential providers, including private for-profit organizations.

In bidding for service contracts the provider organizations strive to design proposals that offer the re- 
quired service at the lowest cost. Social work administrators in the public sector responsible for negotiating the service contracts with private providers are looking to obtain the highest quality of service for the lowest cost. In the course of choosing among competing proposals from private providers social work administrators are increasingly being called upon to perform a function that most of them were not required to execute 10-to-15 years ago and for which few have received adequate professional preparation. Even todayprofessional social work training rarely addresses the issues and challenges that arise in the design and administration of purchase of service contracts.

The administrative culture of social work in the public social services has traditionally placed little emphasis on analyzing the cost of public provisions. Indeed, there is little incentive to reducing the costs of public social services, in part because that might send a message suggesting the need for services was declining. Few administrators want to see their organizational budgets shrink.

Negotiating third-party purchase of service contracts with the private sector requires a different perspective on the cost of services, particularly when dealing with profit making providers. Purchase-ofservice negotiations, for example, often require that social work administrators have expertise in unit cost analysis. Currently many social work administrators in the public sector would have a difficult time responding to the question: How much does it cost to provide a unit of service?

When these services are outsourced, it is often necessary to be able to formulate a precise specification of what it is that the public agency is buying - the units of social service - and how much each of these units cost. The arithmetic of unit cost analysis is simple to compute - divide the total annual costs (as shown in a functional budget) for a service component by the units of interest. The essential challenge for social work administrators in negotiating purchase of service contracts involves specifying the service units of interest. There are at least three basic units of interest:

- cost per consumer - here the interest is in the number of clients served

- cost per the provision delivered - here the interest is in the range and quality of service functions

- $\quad$ cost per unit of result - here the interest is in the outcomes the purchaser hopes to achieve
These calculations depend largely on the scope and complexity of the service functions under consideration. Some social welfare functions involve highly standardized and uniform procedures as, for example, providing immunization for school children. The unit of service is discrete and the cost can easily be calculated either in terms of the number of children served or the actual provision -- the number of flu vaccines administered. The results can be measured according to the extent to which therwere fewer flu illness among those receiving the vaccinations.

However, many social welfare functions are individually tailored and multifaceted involving a range of services that are variable and comprehensive in nature. Taking a more complex example let us consider nursing home placement for the elderly, which, encompasses a twenty-four-hour-a-day operation that includes food, shelter, care, and therapeutic activities. Although the cost per consumer is the easiest to define and measure, from a purchase of service perspective it is the least effective, since with complex services involving comprehensive care we do not know exactly what is being bought for the price. Consider the issue of quality in nursing home care as applied to the most basic components of this program: daily professional supervision, shelter and meals. In regard to supervision, a purchase of service contract would surely specify the staff/client ratio in the home at all times, and probably the level of professional training. As for meals, the contract would certainly specify the number of meals (three daily per client, plus an afternoon snack) and basic nutritional standards. And for shelter there would be a bed in a room. However, on the provision in all of the these areas there is a range between minimal and optimal quality. The easily measured criteria of staffing ratios, education, days of training, number of meals, nutritional standards, and beds fail to capture some of the most essential qualitative aspects of these provisions: neither maturity and warmth of staff (and where they got their education) nor taste, texture, and presentations of food enter the calculations. To what extent does the description of shelter specify the amount of personal space and privacy? And then there is the more perplexing question of what constitute all the relevant components: does the contract specify the nitty gritty of how often the sheets are changed on beds, how light and airy the rooms are, and how warm the thermostat is kept? How often do purchase-of-service-contracts specify all the relevant service components and the appropriate quality standards? 
The problem here is illustrated in a study comparing profit-oriented and non-profit service providers, which reveals that for-profit providers have a relative advantage when calculated simply on the basis of cost per consumer in nursing homes. But what about the quality of care? Weisbrod and Schlesinger (1986) found that for-profit providers had a lower cost per client, but also employed fewer staff per patient than nonprofit homes, and that the staff in for-profit facilities administered considerably higher dosages of sleeping medication to their clients than in non-profit homes.It is probably easier and less expensive to care for people who are asleep much of the time. What this represents in regard to the quality of care is another issue.

The costs for lack of experience and expertise in negotiating purchase of service contracts is revealed in a study of welfare offices in the United State, which contracted out employment services under the 1996 welfare policy reforms. An analysis of four urban areas found that for components of service that sounded quite similar. The average per person reimbursement differed by as much as $130 \%$ among the four sites. The largest cost differences were found among the sites in which the social service administrators tended to accept the price set by service providers (Derr, Anderson, Trippe and Paschal, 2000).
In sum, the increasing privatization of the welfare state poses a challenge to social work administrators in the public sector as they negotiate contracts for service delivery with private agencies. This development requires a shift in the prevailing culture of public social service administration toward placing greater attention on measuring cost and performance than has been given to services heretofore delivered through the public sector. It is a change that highlights the cost-benefit perspective of the private sector. As mentioned earlier in the analysis of the move toward the enabling state, this shift represents a firm belief in the efficiency and productivity of the culture of capitalism as it operates through the market economy.

There is much to recommend greater attentiveness in professional social work training to measuring the quality, cost, and outcomes of social services. As social work administrators develop these skills and adjust to the culture of market exchange, however, it is well to remember that while this culture has an admonition that "the customer is always right," it also advises "caveat emptor." "Buyer beware" is a warning especially pertinent to third-party purchases in which service providers stand between the public agency buyer and the citizen consumer.

\section{REFERENCES}

Ackerman, S. (1983). Social Services and the Market. Columbia Law Review, 83, 6, pp. 1405-1438. http://dx.doi. org/10.2307/1122493

Adema, W. and Einerhand, M. (1998). The Growing Role of Private Social Benefits. Labour Market and Social Policy - Occasional Papers, 32.Paris: Organisation for Economic Co-operation and Development (OECD). http://dx.doi. org/10.1787/804013113766

Cantillon, B. (2011). The Paradox of the Social Investment State. Growth, Employment and Poverty in the Lisbon Era. Journal of European Social Policy, 21, 5, pp.432-449. http://dx.doi. org/10.1177/0958928711418856

Derr, M., Anderson, J., Trippe, C. and Paschal, S. (2000). The Role of Intermediaries in Linking TANF Recipients with Jobs. Washington, D.C.: Mathematica Policy Research Inc.

European Commission (2011). Study on social services of general interest: Final report.
Eardley, T. (1997). New Relations of Welfare in the Contracting State: The Marketisation of Services for the Unemployed in Australia. Social Policy Research Center Discussion Paper, 79.

Editorial: Social Impact Bonds: Commerce and Conscience. The Economist, February 23,2013, p.71.

Geurts, S., Kompier, M. and Grundemann, R. (2000). Curing the Dutch Disease? Sickness Absence and Work Disability in the Netherlands. International Social Security Review, 53, 4, pp.79103. http://dx.doi.org/10.1111/1468246X.00106

Giddens, A. (1998). The Third Way: Renewal of Social Democracy. Cambridge: Polity Press.

Gilbert, N. (2004). Transformation of the Welfare State: The Silent Surrender of Public Responsibility. New York: Oxford University Press.

Gilbert, N. (2012). The American Challenge in Cross-National Perspective. In Hacker,
J. and O'Leary, A. (eds.), Shared Responsibility, Shared Risk: Governments, Markets and Shared Responsibility in the $21^{\text {st }}$ Century. New York: Oxford University Press, pp. 39-54.

Gilbert, N. and Terrell, P. (2005). Dimensions of Social Welfare Policy. Boston: Allyn and Bacon. http://dx.doi.org/10.1111/ j.1369-6866.2005.00371.x

Hirsch, B. and Macpherson, D. (2011). Union Membership and Data Book: Compilations from the CPS2011. Arlington: Bureau of National Affairs.

Holmqvist, M. (2010). The 'active welfare state' and its consequences. European Societies, 12,2, pp. 209-230. http://dx.doi. org/10.1080/14616690903388960

Hort, S. and Cohn, D. (1995). Sweden. In Johnson, N. (ed.), Private Markets in Health and Welfare. Oxford: Berg Publishers, pp. 169-202.

Hurd, M., Martorell, P., Delavande, E., Mullen, K. and Langa, K. (2013). Monetary 
Costs of Dementia in the United States. The New England Journal of Medicine, 368, 14, pp. 1326-1334. http://dx.doi. org/10.1056/NEJMsa1204629

Jessop, B. (1994). From Keynesian welfare to the Schumpeterian workfare state. In Burrows, R. and Loader, B. (eds.). Towards a Post-Fordist Welfare State? London: Routledge.

Johnson, N. (1995). The United Kingdom. In Johnson, N. (ed.). Private Markets in Health and Welfare. Oxford: Berg Publishers.

Lehto, J. (1999). Universal Right to Public Social and Health Care Services? In Bouget, D. and Palier, B. (eds.). Comparing Social Welfare Systems in Nordic Europe and France. Paris: DRESS/MiRe.

Lundstrom, T. (2000). Non-governmental Actors, Local Administration, and Pri- vate Enterprise: New Models in Delivery of Child and Youth Welfare? Paper presented at the International Conference on Playing the Market Game? University of Bielefeld, March 9 to 11, 2000.

Milward, B. and Provan, K. (1993). The Hollow State: Private Provision of Public Service. In Ingram, $H$. and Rathgeb Smith, S. (eds.). Public Policy for Democracy. Washington, D.C.: The Brookings Institution, pp. 222-240.

OECD (2011). The Future of Families to 2030. Projections, Policy Challenges and Policy Options. A synthesis Report. Paris: Organisation for Economic Co-operation and Development (OECD).

http://dx.doi.org/10.1787/9789264168367-

2-en

http://dx.doi.org/10.1787/97892641683679-en http://dx.doi.org/10.1787/97892641683671-en

http://dx.doi.org/10.1787/97892641683677-en

http://dx.doi.org/10.1787/97892641683678-en

Slettebo, T. (2000). The Consequences of Marketization on Professional Practice and Identity - a Case Study of Outcontracting in the Residential Child and Youth Protection Servies in Norway. Paper presented at the International Conference on Playing the Market Game? University of Bielefeld, March 9 to 11, 2000.

Weisbrod, B. and Schlesinger, M. (1986). Nonprofit Ownership and the Response to Asymmetric Information: The Case of Nursing Homes. In Rose-Ackerman, S. (ed.). The Economics of Nonprofit Institutions: Studies in Structure and Policy. New York: Oxford University Press. 